Article

\title{
Does New Urbanism "Just Show Up"? Deliberate Process and the Evolving Plan for Markham Centre
}

\author{
Katherine Perrott \\ Faculty of Environmental and Urban Change, York University, Toronto, M3J 1P3, Canada; E-Mail: perrottk@yorku.ca
}

Submitted: 5 August 2020 | Accepted: 16 November 2020 | Published: 22 December 2020

\begin{abstract}
This article traces three decades of planning for a Canadian suburban downtown in Markham, Ontario, an early adopter of new urbanism. While leading new urbanist design firm Duany Plater-Zyberk \& Co. (also known as DPZ) produced site plans for both Cornell and Markham Centre, much of the research attention on the implementation of new urbanism has focused on the Cornell development, where build-out began in the 1990s. Construction was delayed in Markham Centre until a decade later and continues today. The article is empirically grounded in a discourse analysis of policy, housing advertisements, and interviews with key actors in the planning and development process. New urbanism's popular influence has led Fulton (2017) to argue that a ubiquitous urbanism now "just shows up." Mainstreaming of new urbanist principles and the discursive framing of planning for Markham Centre as an 'evolution' further underscores this perception. Key actors describe an 'organic' planning process illustrating how the plan has changed in response to shifting market dynamics, political interests, and funding opportunities. The article explores the discourse about new urbanism and argues that in Markham Centre new urbanism has not just shown up, but has rather required a deliberate, collaborative, and adaptable process. Development that is transit oriented and attractive to knowledge economy workers underpins the contemporary vision. New urbanism as a label is losing relevance in Markham, where sprawl represents the past, new urbanism describes the legacy of 1990s planning, and a 'real' competitive urbanism is the vision for the future.
\end{abstract}

\section{Keywords}

discourse; knowledge economy; Markham; new urbanism; organic metaphor; suburban downtown; suburbs; transit-oriented development

\section{Issue}

This article is part of the issue "New Urbanism: From Exception to Norm-The Evolution of a Global Movement" edited by Susan Moore (University College London, UK) and Dan Trudeau (Macalester College, USA).

(C) 2020 by the author; licensee Cogitatio (Lisbon, Portugal). This article is licensed under a Creative Commons Attribution 4.0 International License (CC BY).

\section{Introduction: New Urbanism from Fringe to Centre}

New urbanism emerged 30 years ago as a movement encouraging good design as an alternative to sprawl. Alongside smart growth and sustainable development, new urbanism has been an influential voice among the broader calls within urban planning theory and practice to retrofit, repair, and urbanize the suburbs, (Dunham-Jones \& Williamson, 2009; Gallagher, 2013; Grant, 2006; Tachieva, 2010). At stake for new urbanism is the opportunity to reverse the problems generated by sprawling post-war suburban expansion including environmental damage, social isolation, unmemorable places, and separated, single-function land uses (e.g., residential subdivisions, office parks, and shopping malls) that lead to car dependence and traffic congestion (Duany, Plater-Zyberk, \& Speck, 2000).

Fulton (2017) asserts that now new urbanism has become standard practice and "just shows up" as a "ubiquitous urbanism" that is "no big deal" (para. 4). Does new urbanism just show up? In this thematic issue, authors have been asked to consider Fulton (2017) and debate whether or not new urbanism has gone from the exception to the mainstream of planning to the extent that new urbanism has lost its distinction and relevance as a label. In this article I respond to these questions through an analysis of how planning and development discourse represents Markham Centre, in the Toronto metropoli- 
tan area, as a case study in contemporary new urbanism (Figure 1).

In the 1990s new urbanism emerged as the planning framework for approximately 3,500 hectares of former farmland turned new greenfield development blocks arcing around Markham's built-up edge (Figure 2). Duany et al. (2000) describe the new urbanist vision for Markham's greenfields as "an uncanny inversion of the typical North American city: classic sprawl at the center, surrounded on all sides by a consistent gridded urbanity" (p. 200). The most well-known of these development blocks in the urban planning literature is Cornell, designed by Miami-based leading new urbanist design firm Duany Plater-Zyberk \& Co. (DPZ) who characterized it as "a fairly pure application of the neighbourhood con- cept" (Duany et al., 2000, p. 199). Lesser known is that DPZ also designed a neighbourhood plan for Markham Centre, which due to wastewater servicing and other constraints was not implemented at the same time as Cornell. Markham Centre is now under construction. Because of the lag between plan and development, this case study offers the opportunity to examine implementation of a new urban vision over an extended time period.

The subtitle of this thematic issue is 'the evolution of a global movement.' In this article I examine how key actors in the planning and development process mobilize a discourse of 'evolution' to characterize the changing vision for Markham Centre. Discourse does 'rhetorical work' in building preferred narratives that frame policy issues, define problems, and articu-

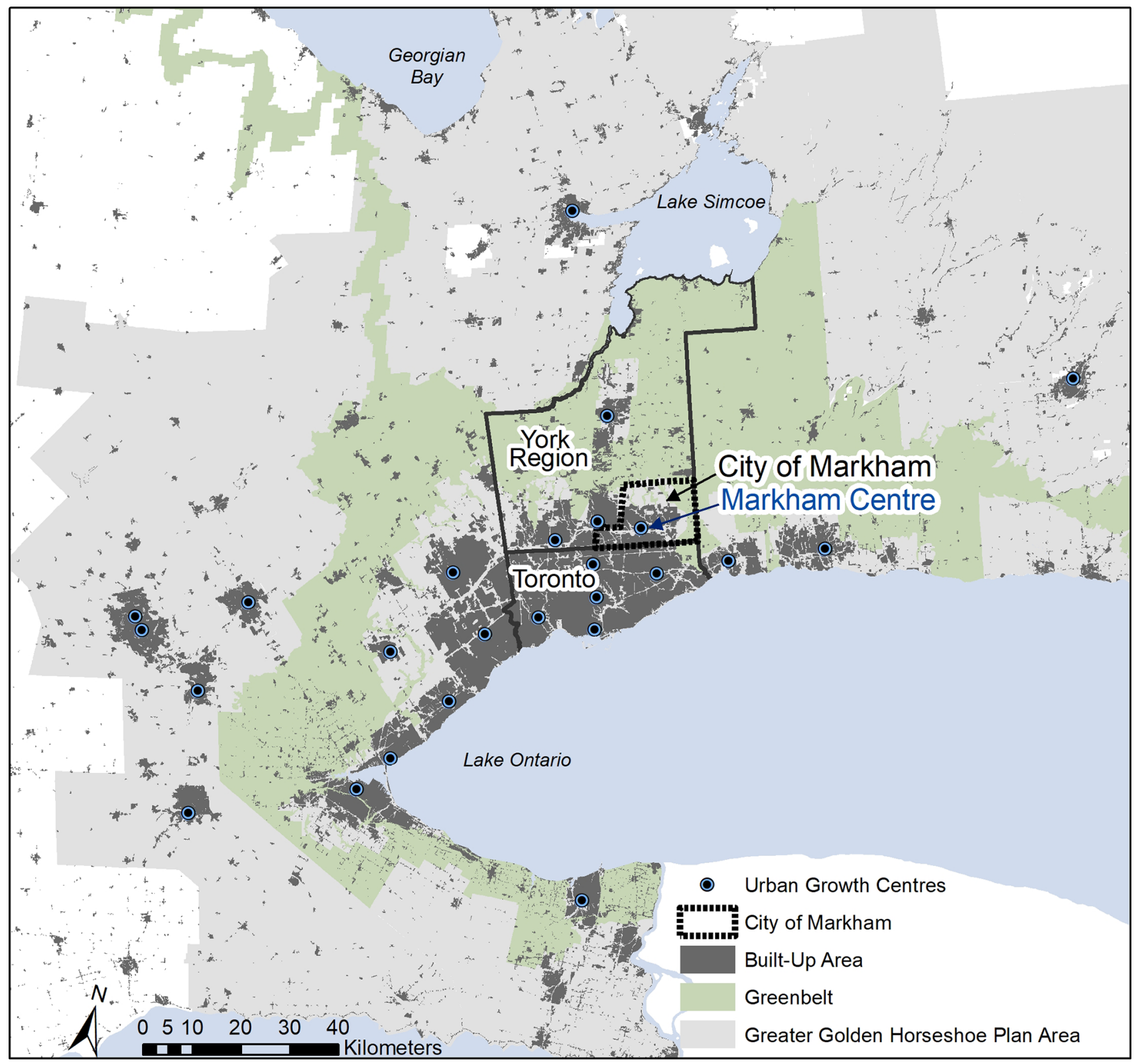

Figure 1. Markham in the context of the Greater Golden Horseshoe plan area. Markham Centre is located approximately 30 kilometres away from the City of Toronto central business district. Source: Author, based on open source data from the Province of Ontario. 


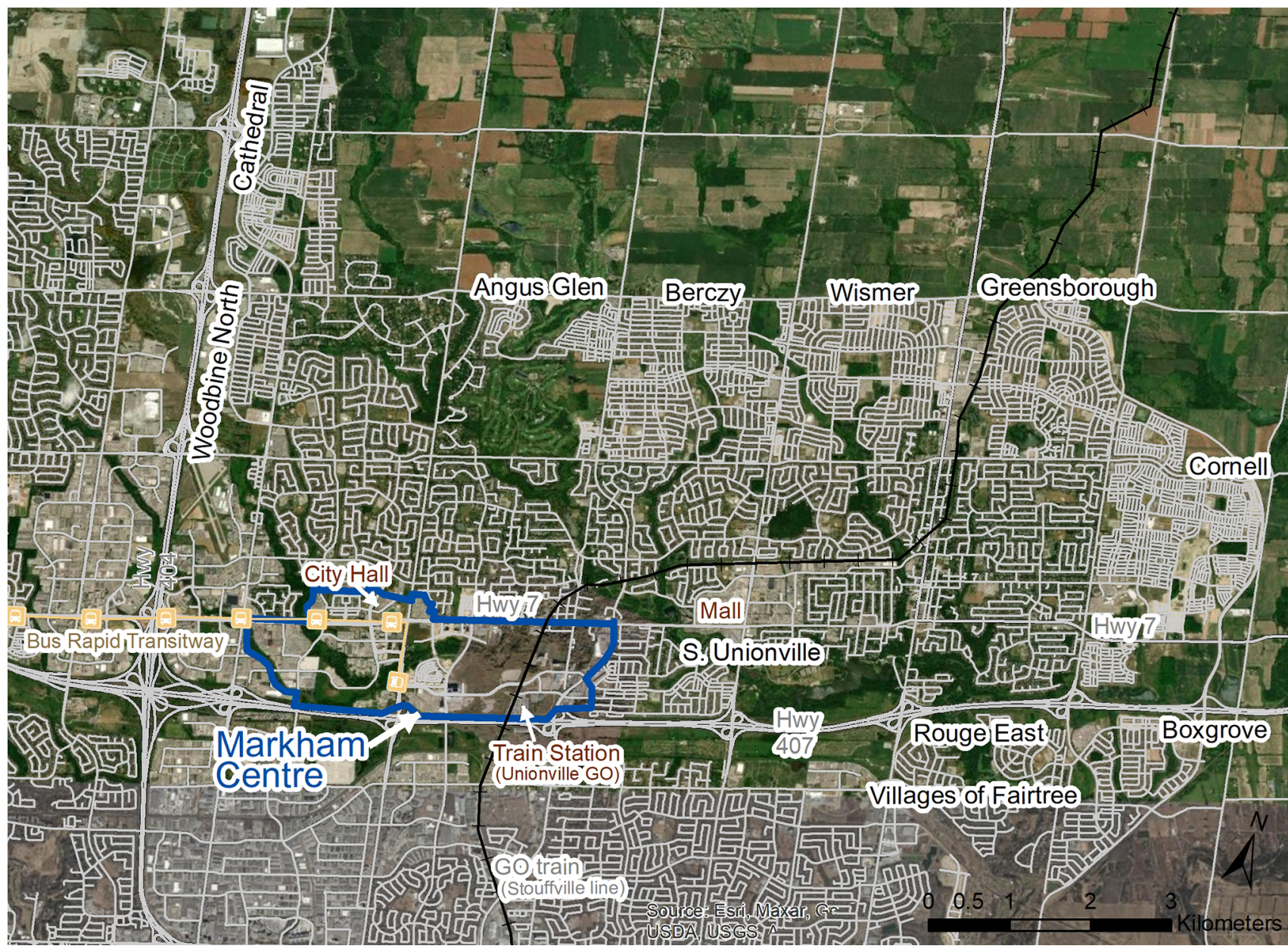

Figure 2. Markham's new urbanist development blocks. Source: Author, based on open source data from the Province of Ontario, York Region, and City of Markham.

late solutions (McArthur \& Robin, 2019). The literature has drawn attention to new urbanism's use of evolutionary discourse and organic metaphors, such as 'transect planning' (Duany \& Talen, 2002), which work to naturalize new urbanism's design prescriptions and to generate support for a vision that is framed as the natural evolution of the suburbs (Grant \& Perrott, 2010; Thompson-Fawcett, 1998). Urban planning is a change management process and thus naturalizing change is a powerful discourse when interests vary and financial stakes are high. Discourse analysis de-naturalizes and draws attention to how new urbanism is constituted in and through narratives and images.

The problem with the rhetorical work of 'evolution' is that it obscures the actual work of deliberate political and professional actions that produce planning visions and guide their implementation. The naturalizing function of discourse, alongside the movement's widespread influence and appeal, reinforce new urbanism's takenfor-granted character, appearing as "no big deal" (Fulton, 2017, para. 4). I argue that counter-sprawl planning strategies, including new urbanism, have gone from the exceptional to the mainstream in Markham and the surrounding region; however, new urbanism far from "just shows up" as Fulton (2017, para. 4) claims. Despite the use of organic metaphors, practitioners credit a range of factors leading to the deliberate production of urbanism in Markham Centre: Professional buy-in, political champions, public transit funding, public-private partnerships, and a high price housing market that creates demand for condominium apartments in a suburban location. The discursive framing of long-range planning as an 'organic process' or 'evolution' indicates the importance that practitioners place on their ability to adapt a plan in response to economic and political change.

I further argue that the label is losing relevance in a discourse that eliminates the 'new' to emphasize authenticity through 'real' and 'true' urbanism. Over time, new urbanism in Markham has gone from fringe to centre, first with the neotraditional village character of Cornell on the built-up fringe of the Town of Markham to the production of Markham Centre, an intentionally urbane, transit-oriented central downtown for the renamed City of Markham. In the contemporary moment and rooted in the specificities of place, the planning approach for Markham Centre has become conceptually and discursively intertwined with competition and laying the groundwork for a built form that can attract 
knowledge economy workers. Discursively, sprawl is the past, new urbanism is legacy, and competitive urbanism is the future.

\section{New Urbanism's Heterogeneous History}

New urbanism promotes built environments that are pedestrian-scaled, supportive of mass transit, diverse in land use, and shaped by well-defined, universally accessible public realms that celebrate local environments, histories, and building practices (Congress for the New Urbanism, 1996). From the outset of the movement 'new urbanism' has been an "umbrella term" (Bohl, 2000, p. 762) encompassing various planning and design approaches reacting to sprawl, and there have been multiple new urbanisms, or what Grant $(2006$, p. 3) calls "new urban approaches." Two of these predominant approaches in Canada and the United States are Traditional Neighbourhood Design and Transit Oriented Development (Grant, 2006; Lehrer \& Milgrom, 1996). Traditional Neighbourhood Design valorizes the form and architectural aesthetic of the 'authentic' urbanity represented by pre-war built form as a response to the ugliness of suburban sprawl (Duany et al., 2000). Traditional Neighbourhood Design's proponents present the past as a solution for the future, influenced by Leon Krier who rejected the modernist city and called for a return to a pre-industrial, 'organic,' and authentic European 'quartiers' urbanism (Bohl, 2000; Grant, 2006; ThompsonFawcett, 1998). Transit Oriented Development promotes the ideal of a mix of high-density uses and public spaces within pedestrian pockets around transit hubs (Calthorpe, 2002; Calthorpe \& Poticha, 1993).

In 1993, the proponents of Traditional Neighbourhood Design (including Andres Duany and Leon Krier) and Transit Oriented Development (including Peter Calthorpe) convened for the first Congress for the New Urbanism and eventually merged their ideas into a Charter of the New Urbanism (1996) that articulates the principles of the movement. New urbanism reflects the grafting of the two predominant branches of Traditional Neighbourhood Design and Transit Oriented Development and has come to represent design for communities that are "compact, walkable, mixed-use, and transit-friendly and contain a diverse range of housing" (Knaap \& Talen, 2005, p. 109). New urbanism draws on a lineage of normative planning ideals, including those promoted by Ebenezer Howard, Lewis Mumford and Jane Jacobs, and at its inception, the movement shared values with other popular concepts including sustainable development, smart growth, urban villages, and the urban renaissance (Grant, 2006, 2009; Knaap \& Talen, 2005). Through implementation in planning practice, new urbanism has been blended with these other concepts, been packaged to emphasize certain principles over others, and has been adapted to the specific conditions of different places, producing the heterogeneous character of new urbanism.

\section{Producing New Urbanism}

Case study research has illustrated how variable new urban approaches emerge according to the specificities of place. One vein of case study research focuses on the built form, measuring how new urbanist developments measure up against the movement's own principles and conventional subdivisions. For example, the Cornell neighbourhood in Markham has been shown as distinctive for having narrower lots than the previous Markham norm, back lanes, houses with front porches, and a central plaza with shopping and offices. Research has found Cornell to have a close alignment in physical form with new urbanist ideals (Thompson-Fawcett \& Bond, 2003). When compared with conventional suburban neighbourhoods, Cornell has higher densities (Gordon \& Vipond, 2005), improved street connectivity (Xu, 2017), and more walking and cycling (Tomalty, Haider, \& Fisher, 2011). Research on Cornell has also employed resident surveys to assess housing trajectories (Skaburskis, 2006), and perceptions of neighbourhood and community (Markovich \& Hendler, 2006).

Other case study research attends to how new urbanism is "co-constituted by the practices of situated interpretative communities of development and planning actors" rooted in the local political, historical, regulatory and market contexts (Moore, 2010, p. 103). Methodologically, these studies often analyze discourse in interviews with key actors, policy, and/or development advertisements. This literature highlights how new urbanist principles can be variably selected with key actors citing a range of factors accounting for the successes and challenges of implementing new urbanism including: Values, norms, and priorities among professional planners and developers (Grant, 2006; Moore, 2013; Trudeau, 2018), political will, governance structures and regulatory regimes (Gordon \& Tamminga, 2002; Grant, 2009; Moore, 2010), housing and retail markets (Grant \& Perrott, 2009, 2010), location context of developments, such as infill or greenfield (Grant \& Bohdanow, 2008), typological distinctions such as mainstream, dense, or hybrid (Trudeau, 2013), and municipal fiscal motivations (Sweeny \& Hanlon, 2016). Studies of new urbanist housing advertisements have found representations of nostalgia for an imagined past, homogeneous representations of would-be residents, and places where people can live in harmony with nature (Till, 2001; Winstanley, Thorns, \& Perkins, 2003). New urbanism's inconsistent implementation has led to criticisms that it merely produces prettier, denser sprawl, and faux urban developments (Fulton, 2017; Grant, 2006; Lehrer \& Milgrom, 1996).

\section{Method: Discourses of New Urbanism}

This article examines the discourse of key actors (planners, politicians, developers) in the intersecting processes of planning and development. Discourse is defined as "a group of statements which provide a language for talk- 
ing about-a way of representing the knowledge abouta particular topic at a particular historical moment" (Hall, 2001, p. 72). My approach attends to how discourse frames problems and solutions, constitutes agendas for action, and sustains preferred narratives (Harvey, 1996; Lees, 2004). This approach aligns with Moore's (2013) direction that research on new urbanism usefully focuses on constitutive social practices, alliances, collaborations, contestations, and development pathways rather than fixating on the extent to which case studies have imported new urbanism's universalized charter principles.

The findings presented in this article are drawn from a larger study on reinventing the suburbs in the Toronto metropolitan region, where I conducted semi-structured, approximately one-hour interviews with 60 participants in 2015 and 2016. Of this broader sample, 10 planners worked within the City of Markham, York Region wherein Markham is located, the York Region Transit agency, or the Provincial government. Three politicians sat on Markham's City Council. One interview participant represents the primary landholder and developer in Markham Centre. Where quoted in this article, participants are represented by an anonymous alphanumeric code, (e.g., P01 for planner, C01 for councillor, and D01 for developer). The Markham Official Plan, and the regional Growth Plan form the primary planning policy documents analyzed for this article. Of the broader sample of website and homebuilding magazine advertisements run between 2012 and 2016, 36 developments were within Markham, including five within Markham Centre.

This article reports findings from a text-based discourse analysis of the policies, transcribed interviews, and advertisement rhetoric. I thematically and iteratively coded texts starting with a base codebook informed by the literature and developed additional themes as they emerged across a preliminary sample of sources (Saldana, 2009). Interview questions included asking about planning vision, change in development patterns over time, and the successes and challenges of implementing key planning goals. I was interested in how key actors described both the place of Markham Centre, and its planning process. Through a close reading of policies and advertisements I coded for descriptions of place and location, transit, mobility options, lifestyle, and aspirations. In this article I compare discourse across different actors and sources of discourse, and consider how Cornell and Markham Centre are differently envisioned in policy and sold in advertisements. Together, the interview, policy, and advertising analyses present intertextual evidence of the discursive strategies employed in the place image production and development of Markham Centre as a product of over 30 years of new urbanism-influenced planning.

\section{New Urbanism Mainstreamed in Canadian Planning Principles and Policy}

Markham is located in Canada's largest metropolitan region around the City of Toronto, where growth man- agement is a central feature in land use planning policy. The wider Greater Golden Horseshoe planning region has been growing by roughly 100,000 people per year since the 1990s, has a population of over 6.5 million, and is projected to reach 13.5 million by 2041 (Advisory Panel, 2015). The City of Markham had a population of 328,966 in 2016, the latest census year, representing a $90 \%$ increase since the mid-1990s when new urbanism came to influence the municipality's planning (Statistics Canada, 2002; Statistics Canada, 2017). The average price of a detached house in Markham is over \$1.5 million and more than doubled over the past decade (Canada Mortgage and Housing Corporation, 2020). In 2005 the Province established an 800,000 hectare greenbelt and adopted the Growth Plan for the Greater Golden Horseshoe in 2006. The Growth Plan intended to curb sprawl, and built on smart growth and new urbanism policies already adopted in many of the local municipalities, like Markham (Hess \& Sorensen, 2015). The Growth Plan mainstreamed new urbanist principles as 'best practice' across the region (Moore, 2013). Mandating principles and plans, however, has not necessarily guaranteed successful implementation in the region where entrenched infrastructures of car dependence, weak political commitment, and market pressures have limited their success (Filion, 2018; Grant, 2009).

The Growth Plan repackages the principles of new urbanism, and the related concepts of smart growth and sustainability, in the language of 'compact built form' that makes efficient use of infrastructure, and 'complete communities,' which are mixed-use neighbourhoods with convenient access to necessities for daily living and a full range of housing, transportation, public services, and recreation options (Government of Ontario, 2019). The provincial government plays a top-down role in establishing the legal basis for planning and providing a detailed framework for growth management in the Greater Golden Horseshoe, with which municipalities in the region are required to conform, and thus the language of 'compact' and 'complete communities' is reproduced in the local plans. Beyond the Toronto region, 'compact' and 'complete communities' have become shorthand for urbanism throughout Canada (Grant \& Scott, 2012). The influence of these concepts is evident in The Charter for Canadian Urbanism established by the Council for Canadian Urbanism, a group of planning and urban design professionals from across the country. The Charter calls for the urgent implementation of progressive, creative, by-design solutions for "complete, compact, mixed-use, interconnected and vibrant neighbourhoods that prioritize sustainable and healthy mobility choices-walking, biking and transit" to "replace the unsustainable, use-separated, low-density, car-oriented model of the past" (Council for Canadian Urbanism, 2013, para 10). While there are imprints of the American New Urbanism movement established by the Congress for the New Urbanism, the Council for Canadian Urbanism 
Charter specifies "a new Canadian urban model" (2013, para. 10).

A key feature of growth management planning in the Toronto region is the identification of 25 Urban Growth Centres, including Markham Centre, which are planned to hit density targets based on number of residents and jobs. The Urban Growth Centre concept established in the 2006 Growth Plan bears the hallmarks of Transit Oriented Development, emphasizing dense clusters of mixed use within walking distance of regional transit service, while also located close to key highway intersections. Clustering high density buildings into the Urban Growth Centres preserves historically lower density areas and historic village main streets. The Urban Growth Centre policy builds on a legacy of suburban downtown planning in the region since the early 1960 s (Carver, 1962). Suburban downtowns help create new core identities for amalgamated large municipalities including Markham, Vaughan, and Mississauga. Other suburban downtowns represent the hubs of older boroughs of pre-amalgamation Toronto, like Scarborough, and North York. High-rise apartments and offices clustered around city halls, regional shopping malls and their parking lots characterized the development of suburban downtowns through the 1970s and 1980s. Relph (1991) concluded that these downtowns were more suburban than urban, retained relatively low densities due to large parking lots, and were defined by wide arterial roads that continued the dependence on automobiles. Since those observations, there have been continued developments in these nodes, improvements in their connections to local and regional transit systems, and a lifting of height restrictions in Mississauga City Centre. Filion's (2018) study of Toronto-area suburban downtowns built out through the 1970s and 1980s (not including Markham Centre) finds that car-oriented design and shopping malls with large lots for free parking and minimal transit service has prevented a transformation in suburban transportation patterns and ways of life. The more successful of the older Urban Growth Centres concentrate high density mixed land uses, have streets conducive to walking, and are served by high-order transit that connects dense clusters to many destinations in the region (Filion, 2018; Filion, McSpurren, \& Appleby, 2006).

\section{Markham Centre's 'Evolution': Discourses of Origin and Change}

In the late 1980s Markham planned for a new 'Town Centre' that would be linear in form along the spine of Highway 7, bookended by a new city hall and the existing regional shopping mall built in the early 1980s (Town of Markham, 2004, p. 7). Relph (1991) critiqued this plan as a car-oriented and 'disaggregated' vision that would see the suburban downtown "strung out along several kilometres of a provincial highway" (p. 423). Town hall was constructed in 1989, followed by a scattering of high and low density apartments, a hotel, and com- mercial plazas along Highway 7 towards the mall. Other properties in the Town Centre area were planned for conventional subdivisions of detached houses; however, servicing, market, and other constraints left large areas undeveloped. Cornell's new urbanist plan inspired Council and the public to consider a similar approach for the new downtown and move "away from traditional cul-de-sac-y, loopy suburban stuff, to something that's more real" (P04). In 1992, the municipality initiated a visioning process for the 581 hectares of land around Town Hall, which became designated as Markham Centre (Gordon \& Vipond, 2005). Markham re-hired Andres Duany and Toronto architecture firm NORR Group to lead several public design charettes and produce a new urbanist, neotraditional plan (Figure 3). Duany's plan featured ground level retail and services, a wide central boulevard, and no large surface parking lots (Filion, 2009). A planner described it as "a midrise, 8-storey midtown, kind of a downtown" (P04). The Duany Plan was endorsed by Council in 1994, the year that Mayor Donald Cousens was elected, whom one of the current developers describes as a "forward-thinking" champion for the new downtown concept: "He envisioned his community moving from a bedroom community into a true town" (D02). Politicians and planners embraced the DPZ plan: "It had density, it had pedestrian-scale development. It had all these different aspects that we'd never seen in the 905 [suburban phone area code]" (D02).

The developers, however, struggled to make the financial aspects of the DPZ plan work, and over the course of a decade revised the plan to include a business park, a commercial area, and residential quadrants. The primary developers decided that it was still "pretty traditional in land use layout...it just wasn't working. I didn't see it as truly mixed use, so we changed it up" (D02). This time the developers reached out to the other main branch of new urbanism and hired wellknown Transit Oriented Development proponent, Peter Calthorpe to run design charettes and produce images of a downtown that would be "truly mixed" (D02). The plan was refined over time with the largest section of Markham Centre branded as Downtown Markham for the renamed 'City' of Markham. The current vision is a Toronto-inspired urbanism, that incorporates transit, eliminates the business park concept, further integrates the land use mix, and more than doubles the vision for the density of residents and jobs (Figure 4). Construction of offices and apartment buildings took off in the mid2000s following a district energy plant, and development has steadily increased over time. Markham Centre is currently planned to house 41,000 people, educate 10,000 students at a university campus, and provide employment for 41,000 (Remington Group, 2020a). In 2019, the City initiated a process to review and update the secondary (detailed area) plan for Markham Centre, which at the time of writing is still in the public engagement phase. Figure 5 compares streetscape renderings from the DPZ plan in 1994 and the developer's contemporary plan. 


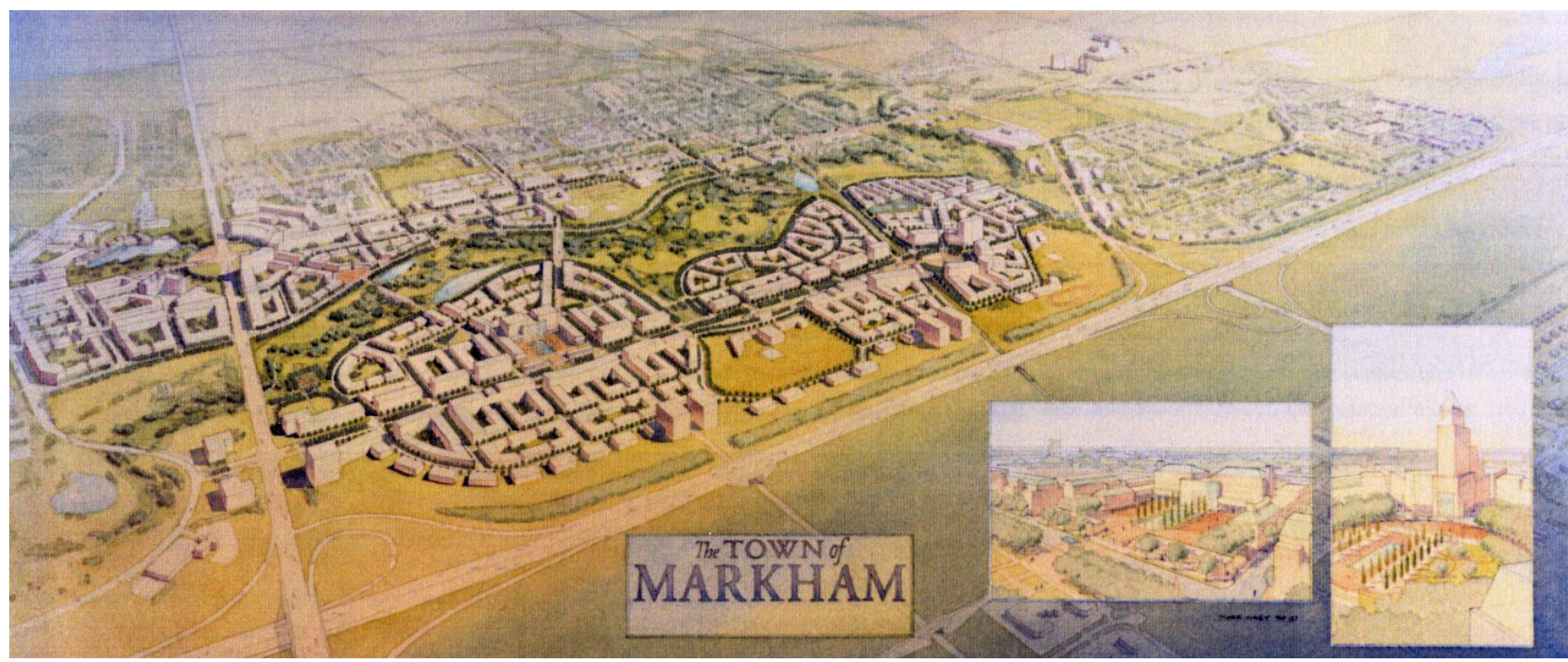

Figure 3. New urbanist vision for Markham Centre produced by DPZ and NORR Group. Source: Courtesy of City of Markham.

Transit has become a central part of the vision for Markham Centre. An existing station part of the Government of Ontario's commuter rail (GO Train) network was upgraded in 2005 and is becoming the anchor of a multimodal mobility hub. In the mid-2000s, York Region Transit announced that a 6-kilometre bus rapid transitway would be constructed along Highway 7 between car lanes, and has been designed for an eventual upgrade to light rail (Figure 6). Construction began in 2010 and it was operational in 2015. The Viva transitway in Markham Centre is one of several bus rapid transitway segments constructed in York Region that are connected through the wider bus network (P27; P28; York Region Rapid Transit Corporation, 2020). The bus rapid transit- way was constructed through a public-private partnership, where York Region Transit sought out a consortium with international experience to build and operate the system using $\$ 1.7$ billion in funding from provincial, federal and regional governments. Collaboration across the public and private sectors, and professional disciplines (especially planning and engineering) was a repeated theme in the story of establishing Transit Oriented Development in Markham Centre.

"A transformation project," not a "transportation or transit project" is how a planner described the interrelationship between the land use plan for Markham Centre and the bus rapid transitway system: "The transformation is an integral story of land use planning

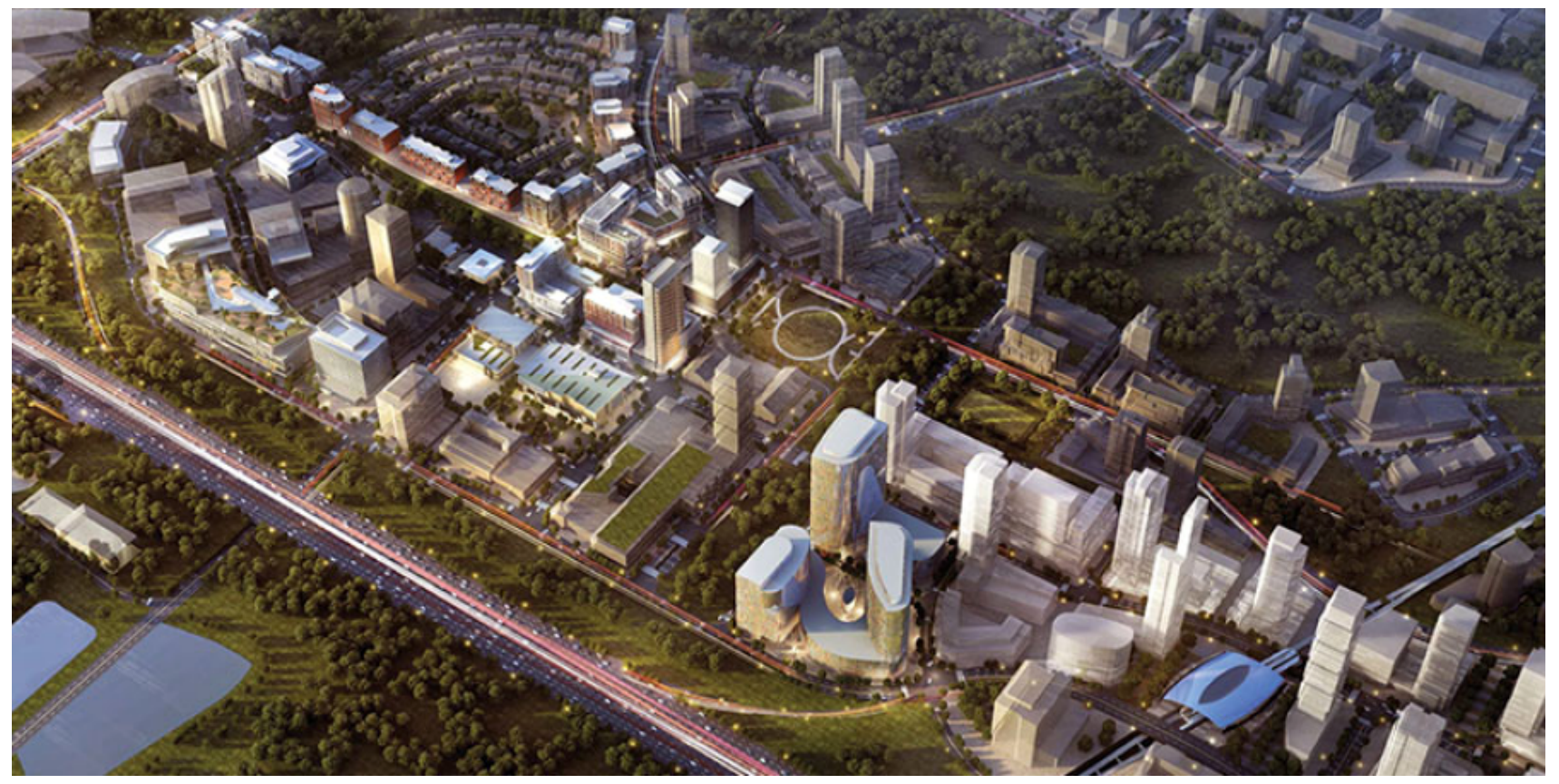

Figure 4. Contemporary Vision for Markham Centre. Source: Remington Group (2020b). 

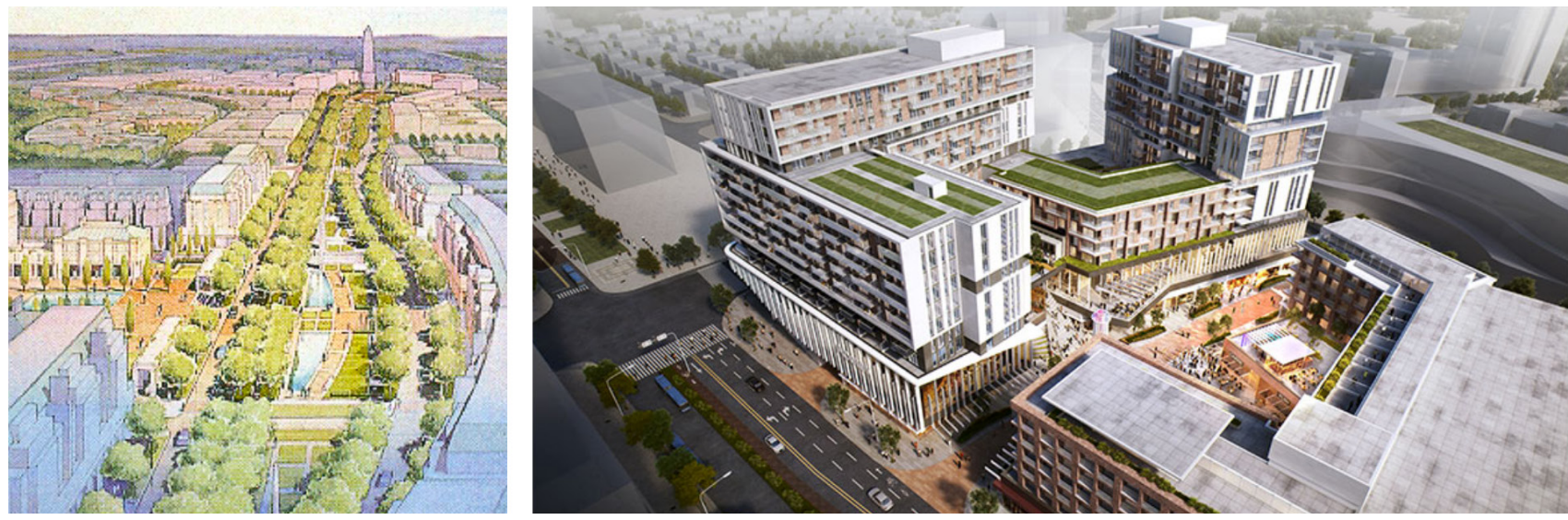

Figure 5. Left: New urbanist streetscape rendering. Source: Courtesy of City of Markham. Right: Contemporary streetscape rendering for Gallery Square Project in Downtown Markham. Source: Remington Group (2020c).

and infrastructure development coming together" (P27). Highway 7 typifies the transportation structure perpetuating car dependence in the suburbs identified by Filion (2018) as limiting efforts to urbanize the suburbs. Interview participants acknowledge the challenges posed by the existing suburban transportation structure, but see the bus rapid transitway as transformational, as was promoted during its construction through the slogan: 'Markham Now; Markham Next' (Figure 7). Disrupting Highway 7 to construct the bus rapid transitway and the resultant dual-function transit and automobile corridor signifies the hybridity and compromise between urbanism and suburbanism that are emerging in the Markham Centre case, and will be inevitable in other suburban locations.

Practitioners characterize Markham Centre's story of origin and change over time as an 'evolution' and an 'organic process,' where time is required to achieve the vision for a 'real' urban place, for example:

I have watched Markham evolve from a very typical suburban community of the 1980 s-large lots, 50' singles, cul-de-sacs - that sort of stuff and it's evolved over time to become what it is now, which is, it's trying to become a real place, a real city. (P04)

Five years from now, there might be something better. Somebody else might look at it and have much better ideas. Allow the plan to evolve. It should be organic. That's what's happening here. It's becoming much more organic. (D02)

I would love to see no cars. I'd love to see people walking and taking transit, but we're not there yet. Eventually we will....It is an evolution. (D02)

The problem is that the whole system is not in place yet. Then it really becomes about time......Again, it's one of those things that will come with the maturity of the rapid transit system. (P27)

What work does the mobilization of this rhetoric do? The repeated references to 'evolving' and 'evolution' in Markham Centre continues new urbanist discourse that naturalizes a normative vision for the built form (Grant, 2006; Grant \& Perrott, 2010; Thompson-Fawcett, 1998).
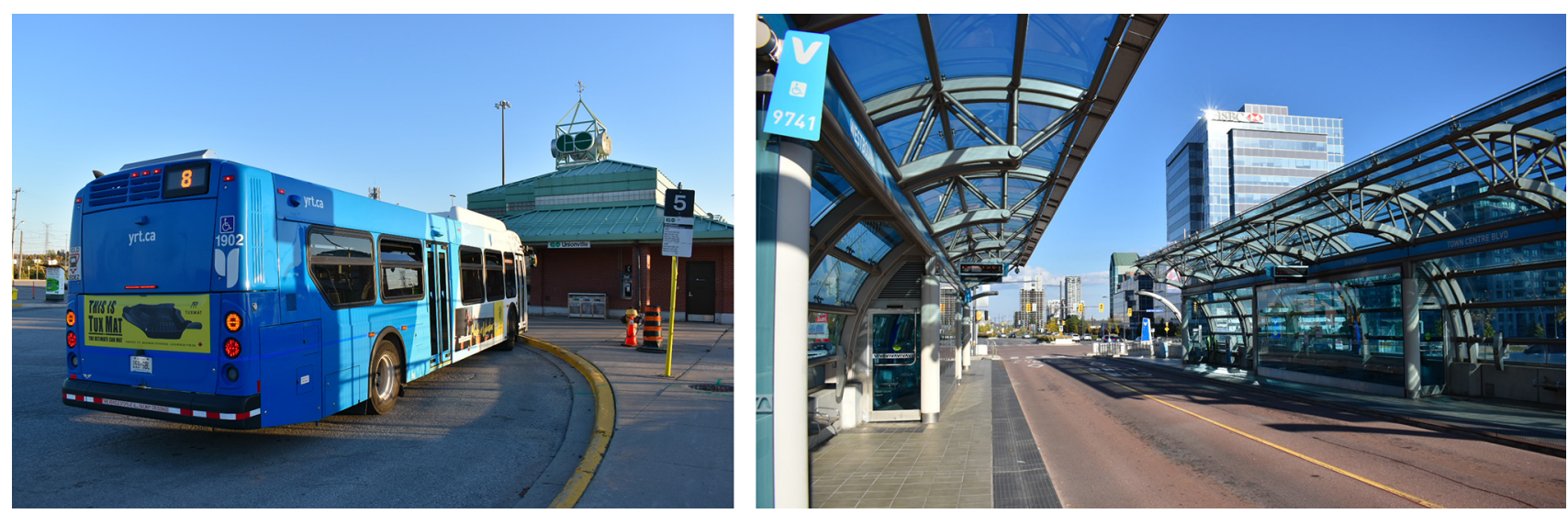

Figure 6. Left: York Region Transit bus at the GO train station. Right: Bus rapid transitway station on Highway 7. Source: Author. 


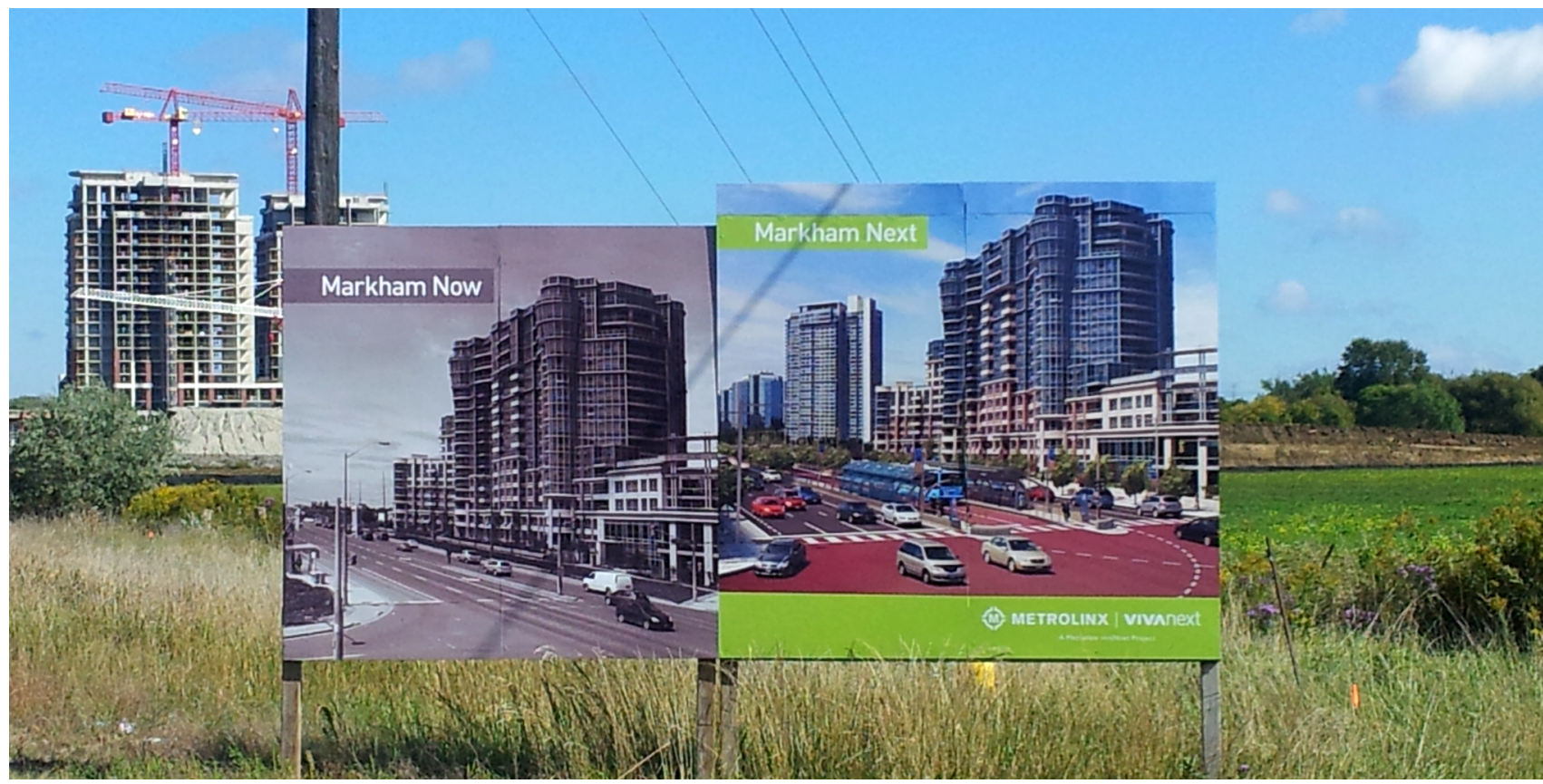

Figure 7. Bus rapid transitway public awareness campaign 'Markham Now; Markham Next.' Source: Author.

In the case of Markham Centre, however, there is more at work in the discourse of evolution. Rather than an easily, naturally evolving process, key actors have worked for decades to forge connections across planning and engineering, land use and transportation, public and private spheres to establish a shared vision and collaborate on its implementation. As an interview participant described: "This isn't casual what's happening here. There are foundational pieces that you put in place...across many different structural elements of what it takes to transform a community....It's very deliberate" (P27). How can a process be both deliberate and organic as described by key actors? An 'organic' and 'evolving' vision is one that can adapt to survive and take advantage of changes to housing markets, political interests and funding opportunities, lifestyles, and policies over time: "You can create the right ingredients to encourage certain forms of development to occur in certain places, but ultimately you have to have the flexibility of view... we need to evolve, right?" (P27). The developer's website characterizes the plan as a "nimble policy framework and forward thinking master plan that would enable Downtown Markham to evolve into York Region's premier hub of culture, education, commerce and entertainment" (Remington Group, $2020 b$, para. 3). Flexibility and openness to new ideas are framed as a necessity in the long-range planning required for sites at this scale. Developing a shared preferred narrative and aligning the goals of actors across city departments and sectors has required a planning context that enables plans to be amended and periodically reviewed and changed. The planning and implementation processes have been deliberate, collaborative, and 'evolutionary' insofar as they have adapted in response to change over time.

\section{Is the Label ‘New Urbanism’ Still Relevant?}

\subsection{Mixing Uses, Mixing Concepts: Discourses of Attraction}

The discursive and conceptual connections between new urbanism, smart growth, and sustainability have been demonstrated in the region's growth management policy and literature (Grant, 2009). The Markham Centre story shows further entwining of anti-sprawl planning approaches with the popular idea that cities should be attracting knowledge economy workers, or the so-called 'creative class' (Florida, 2003). Markham's knowledge economy predates the hype about creative cities as IBM's Canadian head offices have been in Markham since the early 1980s and a software lab was built in 2001 just beyond Markham Centre, but has now been included in the secondary plan boundary. The history of information technology corporations locating in the area is expected to catalyze a cluster in Markham Centre.

Attracting knowledge economy employers and workers as residents is embedded in the discourse about Markham Centre's successful future. Whereas in the past, developers focused on getting employers into office parks, now new players from Human Resources departments are at the negotiating table seeking desirable amenities for employees. A new secondary campus of York University is planned to open in 2023 bringing university students enrolled in digital media, engineering and technology, entrepreneurship, new media and communications programs. The new campus has spurred the development of entertainment options, including a movie theatre, food service, and retailers to appeal to students. The anticipation of university students has fuelled investment in condominium developments 
intended for rental. Amenities are framed as part of the area's attractiveness and thus far include a pool and community centre built as part of the PanAm games, a high school with adjacent sports fields, a YMCA fitness centre, trails and parks. Families were not the originally anticipated residents of Markham Centre's condos, but as more children move into the area, the developers have added a skating rink and carousel that doubles as a public art nod to Canadian symbolism.

Discourse frames the relationship between economic competition and place as inextricably linked and reinforcing: Planning policy states that compact and complete communities rely on a vibrant, competitive economy, whereas practitioners and development advertisements say it the other way around and frame the knowledge economy as reliant on an attractive compact and complete community (Table 1 ). Interview participants describe a scenario where there is a limited demand for Class A office space, university campuses, and highdensity suburban housing, thus Markham Centre has to compete for these with the other suburban downtown Urban Growth Centres and the City of Toronto. Producing a vibrant urban centre with a mix of land uses and amenities that can attract knowledge economy employers and residents is a discourse of survival and competitive advantage.

The planning vision for Markham Centre has come to mix new urbanism with the creative cities concept. Both approaches have been criticized in the literature for producing elitist, exclusionary places (Catungal, Leslie,
\& Hii, 2009; Lehrer \& Milgrom, 1996). The challenge for Markham Centre will be to address these concerns and enable the conditions for diversity and inclusion. The developer explained that their strategy of attracting higher end retailers and restaurants is to distinguish themselves from the surrounding offerings in the suburban plazas, mall and big box power centres as Markham Centre becomes established. The intent is for more diversity and inclusion to 'evolve' in long-run: "Once we get the bigger users in there, and they start seeing that there are all these people it will all evolve and then you'll have everything there" (D02). Housing affordability and a mix of dwelling types are planning goals in Markham and the wider region, but affordability has proven difficult to achieve through the primarily condominium markets in the Urban Growth Centres (Filion, Leanage, \& Harun, 2020). Achieving a diverse urbanity beyond the 'creative class' may require more than planning goals and time. Akin to the efforts that secured transit options in Markham Centre, partnerships, political will, and new policy tools to capture private and public funding may be required to produce rental and affordable housing options, and enable a diverse commercial economy.

\subsection{Sprawl as Past, New Urbanism as Legacy, Urbanism as Future: Discourses on Cornell and Markham Centre}

The Official Plan tells the story of how several villages rapidly expanded into the automobile dependent Town of Markham with "unchecked and poorly managed"

Table 1. Discourses of mixed use and attraction in policy, interviews, and advertisements.

Policy The vision for compact, complete communities also relies on a vibrant, competitive economy that meets the financial needs of residents and the municipality (City of Markham, 2014, pp. 2-8)

Interviews

That's part of what Markham Centre is all about-it's creating a desirable location for employees of choice. We want a complete community that offers the amenities that will attract talent...so it's not just the standard suburban office park. Which is of course deadly boring. It's not a place that you're going to attract a 25-year-old techie to (P04).

You can't force people to come. They have to want to come...you can sprinkle in things that will attract people to come because you need people there (D02).

The younger generation are up-and-coming in their careers and want a more vibrant living area (P28).

We don't want younger people to go downtown [Toronto] any more for entertainment.....We want to have a hub. Especially with the university coming there, so that when the students are going out: 'Hey everything is in the neighbourhood' (C15).

Advertisements York University is opening a new, 21st century campus in the heart of vibrant and growing Downtown Markham. The addition of higher education with more than 4,000 new students to Downtown Markham's existing mix of transit, residential, office, retail and cultural amenities, will make it a complete live-work-play-shop-learn community. Because in Downtown Markham, you have all the right connections (Remington Group, n.d.).

Living at The Hub: Surrounding Riverside is a wealth of amenities, from retail and restaurants to parks and schools, including the new York University campus which should be completed around the same time as Riverside. Viva Transit stops right outside your door, running along the Highway 7 corridor and throughout the region, offer convenient GO Transit connections to Downtown Toronto (Times Group, 2017). 
growth resulting in "sprawl" and traffic gridlock (City of Markham, 2014, pp. 2-3). The Plan notes a shift towards a "more sustainable model of development" in the 1990s with the development of new urbanist Cornell and creating a plan for a Markham Centre (Figures 8 and 9). Table 2 juxtaposes the discourse about Cornell and Markham Centre in the planning policy discourse. Both areas are planned for compact urban form, mixed housing, and employment opportunities as per the regional planning directives for new development. Cornell is planned to have "convenient access to transit" by bus, whereas for Markham Centre seeks out high density "transit-supportive development" to generate users for the bus rapid transitway. Distinct keywords to describe Cornell include: new urbanism, historic village, well designed, and compatible building types. Contrasting keywords to describe Markham Centre include: distinctly urban, higher density, central location, and entertainment centre.

Advertisements for housing developments in Cornell and Markham Centre employ similarly contrasting terms, presented in Table 3. Cornell is new urbanist with walkable, quaint streets in a heritage-like village atmosphere.
Markham Centre is the future, boasting urban condos, entertainment, and world-class businesses at a landmark destination. New urbanism is considered a saleable feature for Cornell, but Markham Centre is distinguished by its urbanity.

Is Markham Centre still 'new urbanism'? Cornell is nearly fully built-out whereas Markham Centre still has more than a decade of buildable parcels remaining. In the Official Plan and advertisement discourse Cornell represents the legacy of New Urbanism and Markham Centre is the distinctly urban future. Interview participants involved with implementing and (re)shaping the plan over time recognize the role that new urbanism has played in Markham Centre's history, while also gesturing towards the waning importance of it as a label that signifies the vision. New urbanism's role in launching Markham Centre is acknowledged as part of "the evolution of Markham Centre" on the public engagement website for the updated secondary plan (City of Markham, 2020, para. 5), but otherwise, the story of Markham Centre is moving on. For one long-time Markham planner:
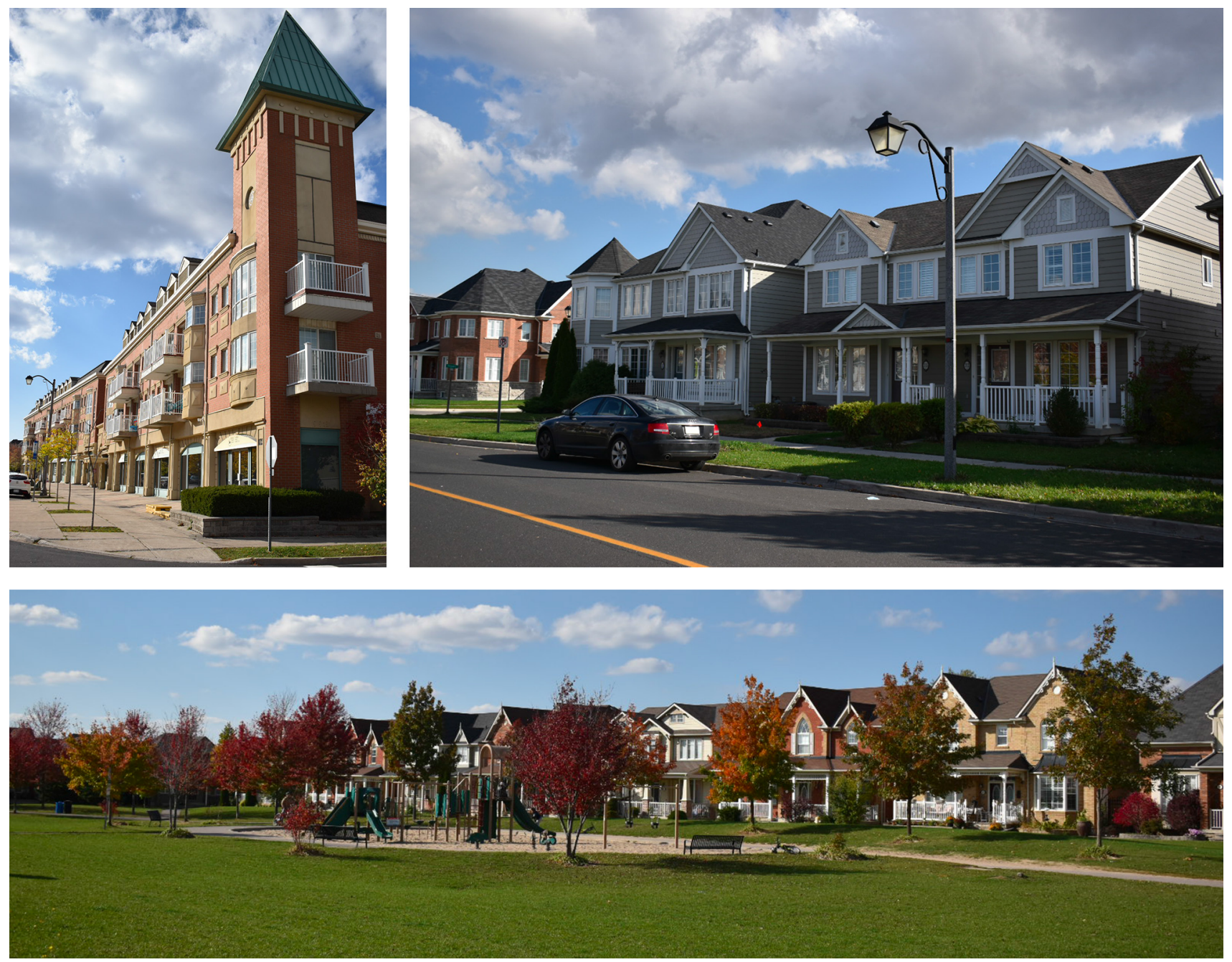

Figure 8. Cornell. Source: Author. 

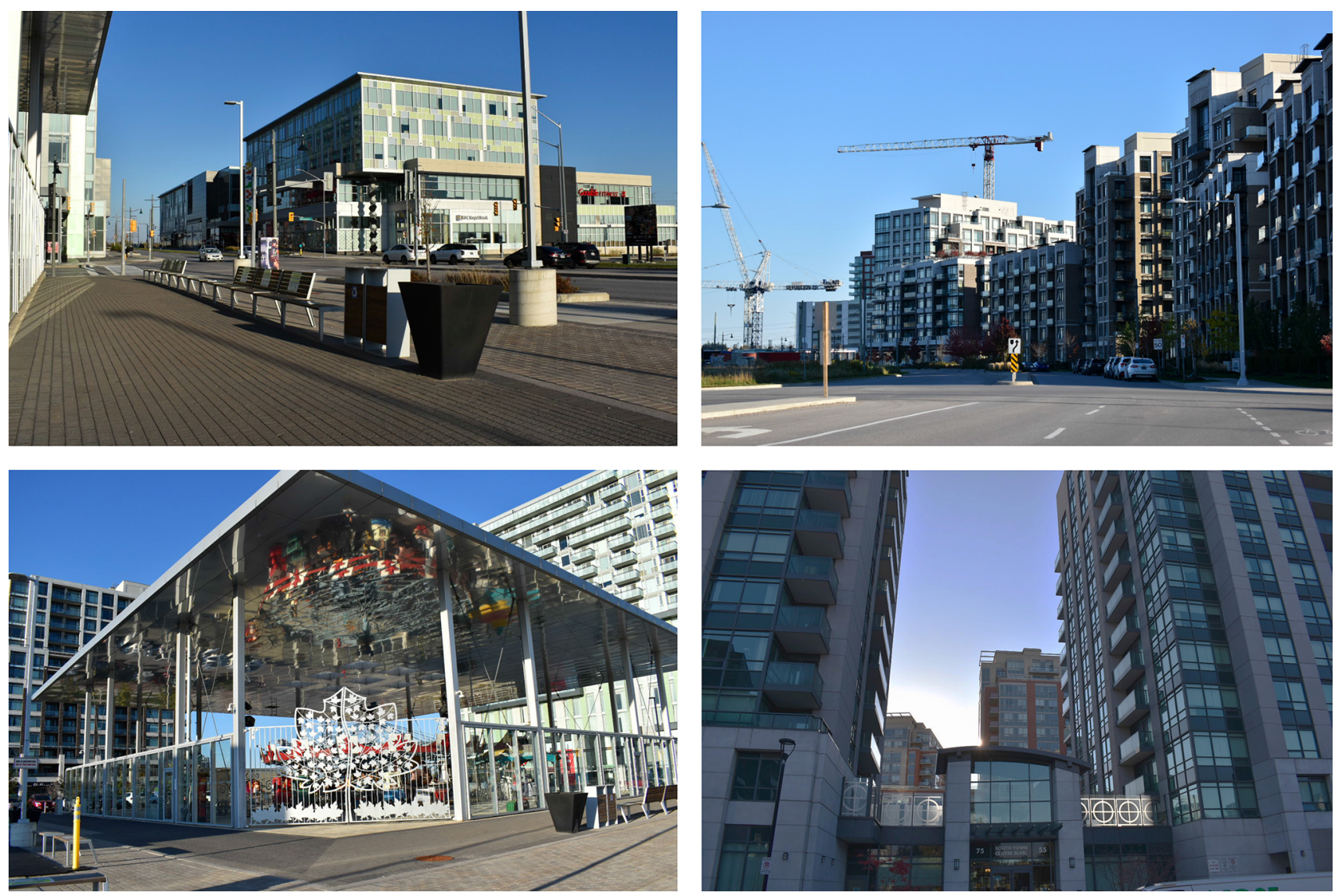

Figure 9. Markham Centre. Source: Author.

New urbanism is still sort of there. I mean new urbanism isn't rocket science. It's building real cities, as they were always built: Street-related buildings, grid pattern streets, a very strong sense of the public realm. And really whether the buildings are low-rise buildings or mid-rise buildings or taller buildings, the principles are all the same....Our focus clearly is on public transit. (P04)
Transit Oriented Development is becoming interwoven with the discourse about attracting the amenities and workers of a knowledge economy. With transit as a bigger focus than traditional design and aesthetics, contemporary planning for Markham Centre demonstrates the ascendance of Transit Oriented Development over Traditional Neighbourhood Design in the contemporary articulation of new urbanism in Markham.

Table 2. Cornell and Markham Centre policy discourse examples.

Cornell
Going back to [Markham's] historic village roots (City of
Markham, 2014, pp. 1-3).
The land use objective for the Cornell district is to
develop a complete and integrated community based on
the principles of new urbanism with a range and mix of
employment and housing, varied and high quality open
space, and convenient access to public transportation,
and public and private services. The uses and activities
shall be distributed within a well designed community
comprising compact urban development defined by
streets and public open spaces as places of shared use,
and compatible building types, achieved through their
scale, massing and relationship to each other, to support
public life and year round activity in the public realm (City
of Markham, 2014, pp. 9-59).

Markham Centre

A new transit-based urban core (City of Markham, 2014, pp. 1-3).

Markham Centre is being planned and developed as Markham's downtown, based on the principles of balanced live-work opportunities, compact urban form, natural heritage protection, and transit-supportive development. With a distinctly urban character, in the form of higher density, mixed-use built form, and high-quality parks and public amenities, it will provide a central location for arts, cultural, sports and entertainment and social activities on a year-round basis (City of Markham, 2014, pp. 2-14). 
Table 3. Cornell and Markham Centre housing advertisement discourse examples.

Cornell Markham Centre

Based on the 'new urban' planning design, Cornell Rouge

community has an open-concept feel with walkable neighbourhoods containing a range of housing types (Madison Homes \& Forest Hill Homes, 2014).

The semis and singles are situated on architecturally controlled streetscapes that enhance the village atmosphere of this New Urbanism neighbourhood. Take a drive through Upper Cornell, and you will appreciate how the rear-lane garages, tree-lined streets, quaint boulevards, authentic heritage town square, and the landscaped neighbourhood parks and nature preserve areas create a unique sense of belonging (Aspen Ridge Homes, 2012).

Nestled into the greater Cornell community, the Grand Cornell Brownstones follow the pedestrian-friendly principles of New Urbanism (Lindvest, 2015).

Our planners call the community design 'new urbanism.' We simply call it wonderful (Aspen Ridge Homes, 2016).

\section{Conclusions: The Ongoing Pursuit of (New) Urbanism in the Suburbs}

The Markham Centre case study provides an opportunity to examine how new urbanism has influenced planning policy and changed the built form within a single region and municipality over time, and how the new urbanist approach itself has adapted to shifting planning goals, market dynamics, and directions of key actors. The case study demonstrates how new urbanist principles have been mainstreamed, but repackaged in the language of compact and complete communities. Key actors describe the plan for Markham Centre as an 'evolution,' but illustrate the opposite. Contrary to Fulton's (2017) assertion that contemporary new urbanism is "no big deal," and that it "just shows up" (para. 4), the Markham Centre case study reveals decades of planning, public funding, "patient money" (P27) invested by developers, and public-private partnerships. To those involved, launching Markham Centre alongside a new rapid transitway is a big deal indeed.

Has the label new urbanism' lost its relevance? Declaring a movement 'new' does not age well. In Markham new urbanism has become strongly associated with Cornell and 1990s aesthetics, densities, and functions. In the Markham Centre case, participants strive for 'real' urbanism as 'new' urbanism is becoming passé and relegated to an origin story. The discursive shift demonstrates that practitioners are aware of the critiques of new urbanism as 'faux,' and thus key actors strive for authenticity. When asked about the successes and challenges of implementing the planning vision, key
Sophisticated urban condos in a spectacular, master-planned community. Steps from, Viva, YRT, shops, cafes and more. This is the future. Make it yours (Remington Group, 2016).

Downtown Markham is at the centre of the area's growth. With distinctive condominium options at an affordable price, a mix of employment and entertainment options, unsurpassed transit access, and now the addition of a world class hotel brand, when you're in Downtown Markham, there really is no reason to go anywhere else (Remington Group, 2013a).

Be among the visionaries who already call Downtown Markham home, and be a part of a landmark destination complete with retail and entertainment, as well as thriving small businesses and global corporations (Remington Group, 2013b).

Modern urban condos in one of North America's most environmentally conscious master-planned communities, surrounded by art, culture, commerce, nature, education and more (Remington Group, 2020c). actors did not show performance measures for how well a new urbanist checklist was being implemented, but rather described the process, partnerships, and politics required to build a new downtown. The discourse about the adaptable 'organic' process, 'nimble policy framework' and need to 'evolve' highlights that for key actors (new) urbanism is a process, not a thing. Urbanizing the suburbs faces substantial challenges. 'New, 'real,' or 'faux,' urbanism are all limited for representing Markham Centre's made-in-the-suburbs hybrid urbanism. The bus rapid transitway public awareness slogan 'Markham Now; Markham Next' captures the notion that pursuing urbanism in the suburbs is an ever-moving process towards what comes next, even while functioning within, and adapting the infrastructures laid down in the past.

\section{Acknowledgments}

The article presents findings from research supported by a Social Sciences and Humanities Research Council of Canada Doctoral Fellowship, an Ontario Graduate Scholarship, and an open access publication grant from York University.

\section{Conflict of Interests}

The author declares no conflict of interests.

\section{References}

Advisory Panel. (2015). Planning for health, prosperity and growth in the Greater Golden Horseshoe: 
2015-2041. Ontario: Advisory Panel. Retrieved from http://www.mah.gov.on.ca/Page10882.aspx

Aspen Ridge Homes. (2012). Upper Cornell (Advertisement). HOMES, 7, 42.

Aspen Ridge Homes. (2016). Upper Cornell. Aspen Ridge Homes. Retrieved from http://www.aspen ridgehomes.com/communities

Bohl, C. C. (2000). New urbanism and the city: Potential applications and implications for distressed inner-city neighborhoods. Housing Policy Debate, 11(4), 761-801.

Calthorpe, P. (2002). The urban network: A new framework for growth. Calthorpe. Retrieved from https://www.calthorpe.com/files/Urban\%20 Network\%20Paper.pdf

Calthorpe, P., \& Poticha, S. (1993). The next American metropolis: Ecology, community, and the American dream. New York, NY: Princeton Architectural Press.

Canada Mortgage and Housing Corporation. (2020). Housing information portal. Canada Mortgage and Housing Corporation. Retrieved from https:// www03.cmhc-schl.gc.ca/hmip-pimh/en\#Profile/ 227027/5/Markham

Carver, H. (1962). Cities in the suburbs. Toronto: University of Toronto Press.

Catungal, J. P., Leslie, D., \& Hii, Y. (2009). Geographies of displacement in the creative city: The case of Liberty Village, Toronto. Urban Studies, 46(5/6), 1095-1114.

City of Markham. (2014). Official plan. City of Markham. Retrieved from https://www.markham.ca/wps/ portal/home/business/planning/official-plan/01official-plan

City of Markham. (2020). Your Markham Centre. Your Voice Markham. Retrieved from https:// yourvoicemarkham.ca/YourMarkhamCentre

Congress for the New Urbanism. (1996). The charter of the New Urbanism. Congress for the New Urbanism. Retrieved from https://www.cnu.org/who-weare/charter-new-urbanism

Council for Canadian Urbanism. (2013). The charter for Canadian urbanism. Toronto: Council for Canadian Urbanism. Retrieved from https://www.canu.ca/thecharter

Duany, A., Plater-Zyberk, E., \& Speck, J. (2000). Suburban nation: The rise of sprawl and the decline of the American dream. New York, NY: North Point Press.

Duany, A., \& Talen, E. (2002). Transect planning. Journal of the American Planning Association, 68(3), 245-266.

Dunham-Jones, E., \& Williamson, J. (2009). Retrofitting suburbia: Urban design solutions for redesigning suburbs. Hoboken, NJ: John Wiley \& Sons.

Filion, P. (2009). The mixed success of nodes as a smart growth planning policy. Environment and Planning B: Planning and Design, 36(3), 505-521.

Filion, P. (2018). Enduring features of the North American suburb: Built form, automobile orientation, suburban culture and political mobilization. Urban Planning, 3(4), 4-14.
Filion, P., Leanage, N., \& Harun, R. (2020). Residential intensification at the interface of market-driven development and planning: Uneven residential intensification outcomes in Toronto. Urban Policy and Research, 38(4), 307-320.

Filion, P., McSpurren, K., \& Appleby, B. (2006). Wasted density? The impact of Toronto's residential-densitydistribution policies on public-transit use and walking. Environment and Planning A, 38(7), 1367-1392.

Florida, R. (2003). Cities and the creative class. City \& Community, 2(1), 3-19.

Fulton, W. (2017). The 'New Urbanism' movement might be dead. Governing Magazine. Retrieved from https://www.governing.com/columns/urbannotebook/gov-new-urbanism.html

Gallagher, L. (2013). The end of the suburbs. New York, NY: Portfolio/Penguin.

Gordon, D., \& Vipond, S. (2005). Gross density and new urbanism: Comparing conventional and new urbanist suburbs in Markham, Ontario. Journal of the American Planning Association, 71(1), 41-54.

Gordon, D. A., \& Tamminga, K. (2002). Large-scale traditional neighbourhood development and preemptive ecosystem planning: The Markham experience, 1989-2001. Journal of Urban Design, 7(3), 321-340.

Government of Ontario. (2019). A place to grow: Growth plan for the Greater Golden Horseshoe. Toronto: Government of Ontario. Retrieved from https://www.ontario.ca/document/place-growgrowth-plan-greater-golden-horseshoe

Grant, J. (2006). Planning the good community: New urbanism in theory and practice New York, NY: Routledge.

Grant, J. (2009). Theory and practice in planning the suburbs: Challenges to implementing new urbanism, smart growth, and sustainability principles. Planning Theory \& Practice, 10(1), 11-33.

Grant, J., \& Bohdanow, S. (2008). New urbanism developments in Canada: A survey. Journal of Urbanism: International Research on Placemaking and Urban Sustainability, 1(2), 109-127.

Grant, J., \& Perrott, K. (2009). Producing diversity in a new urbanism community: Policy and practice. Town Planning Review, 80(3), 267-289.

Grant, J., \& Perrott, K. (2010). Where is the cafe? The challenge of making retail uses viable in mixed-use suburban developments. Urban Studies, 48(1), 177-195.

Grant, J., \& Scott, D. E. (2012). Complete communities versus the Canadian dream: Representations of suburban aspirations. Canadian Journal of Urban Research, 21(1), 1-26.

Hall, S. (2001). Foucault: Power, knowledge and discourse. In M. Wetherell, S. Taylor, \& S. J. Yates (Eds.), Discourse theory and practice: A reader (pp. 72-81). Thousand Oaks, CA: SAGE.

Harvey, D. (1996). Justice, nature and the geography of difference. Malden, MA: Wiley-Blackwell. 
Hess, P. M., \& Sorensen, A. (2015). Compact, concurrent, and contiguous: Smart growth and 50 years of residential planning in the Toronto region. Urban Geography, 36(1), 127-151.

Knaap, G., \& Talen, E. (2005). New urbanism and smart growth: A few words from the academy. International Regional Science Review, 28(2), 107-118.

Lees, L. (2004). Urban geography: Discourse analysis and urban research. Progress in Human Geography, 28(1), 101-107.

Lehrer, U. A., \& Milgrom, R. (1996). New (sub)urbanism: Countersprawl or repackaging the product. Capitalism Nature Socialism, 7(2), 49-64.

Lindvest. (2015). Grand Cornell (Advertisement). Condo Life, 5, 50.

Madison Homes, \& Forest Hill Homes. (2014). Cornell Rouge (Advertisement). New Home Guide, 22(16), 43.

Markovich, J., \& Hendler, S. (2006). Beyond "soccer moms:" Feminist and new urbanist critical approaches to suburbs. Journal of Planning Education and Research, 22, 410-427.

McArthur, J., \& Robin, E. (2019). Victims of their own (definition of) success: Urban discourse and expert knowledge production in the liveable City. Urban Studies, 56(9), 1711-1728.

Moore, S. (2010). 'More Toronto, naturally' but 'too strange for Orangeville': De-universalizing new urbanism in Greater Toronto. Cities, 27(2), 103-113.

Moore, S. (2013). What's wrong with best practice? Questioning the typification of new urbanism. Urban Studies, 50(11), 2371-2387.

Relph, E. (1991). Suburban downtowns of the Greater Toronto Area. The Canadian Geographer/Le Géographe Canadien, 25(4), 421-425.

Remington Group. (n.d.). York Condos. Downtown Markham. Retrieved from https://downtown markham.ca/residential/york-condos

Remington Group. (2013a). The Signature Condominium Collection (Advertisement). Condo Life, 11, 25.

Remington Group. (2013b). The Benchmark Town Manors (Advertisement). HOMES, 3(3), 61.

Remington Group. (2016). York Condos (Advertisement). Condo Life, 3, 17.

Remington Group. (2020a). Downtown Markham demographics. Downtown Markham. Retrieved from https://downtownmarkham.ca/retailcommercial/demographics

Remington Group. (2020b). About Downtown Markham. Downtown Markham. Retrieved from https://downtownmarkham.ca/about/downtownmarkham

Remington Group. (2020c). Gallery Square. Downtown Markham. Retrieved from https://downtown markham.ca/residential/gallery-square

Saldana, J. (2009). The coding manual for qualitative researchers. London: Sage.

Skaburskis, A. (2006). New urbanism and sprawl: A Toron- to case study. Journal of Planning Education and Research, 25(3), 233-248.

Statistics Canada. (2002). 2001 Community profiles. Statistics Canada. Retrieved from https://www12. statcan.gc.ca/english/profil01/CP01/Details/Page. $\mathrm{cfm}$ ?Lang=E\&Geo1=CSD\&Code1=3519036\&Geo2= PR\&Code2=35\&Data $=$ Count\&SearchText=Markham\& SearchType=Begins\&SearchPR=01\&B1=All\&Custom=

Statistics Canada. (2017). Census profile, 2016 Census. Statistics Canada. Retrieved from https:// www12.statcan.gc.ca/census-recensement/2016/ $\mathrm{dp}-\mathrm{pd} /$ prof/index.cfm? ?ang $=\mathrm{E}$

Sweeny, G., \& Hanlon, B. (2016). From old suburb to postsuburb: The politics of retrofit in the inner suburb of Upper Arlington, Ohio. Journal of Urban Affairs, 39(2), 241-259.

Tachieva, G. (2010). Sprawl repair manual. Washington, DC: Island Press.

Thompson-Fawcett, M. (1998). Leon Krier and the organic revival within urban policy and practice. Planning Perspectives, 13, 167-194.

Thompson-Fawcett, M., \& Bond, S. (2003). Urbanist intentions for the built landscape: Examples of concept and practice in England, Canada and New Zealand. Progress in Planning, 60, 147-234.

Till, K. E. (2001). New urbanism and nature: Green marketing and the neotraditional community. Urban Geography, 22(3), 220-248.

Times Group. (2017). Riverside Condos. Uptown Markham. Retrieved from http://uptownmarkham. com/riverside/neighbourhood.html

Tomalty, R., Haider, M., \& Fisher, S. (2011). Comparing Canadian new urbanist and conventional suburban neighbourhoods. Plan Canada, Volume(Issue), 20-25.

Town of Markham. (2004). Markham Centre performance measures document: The Markham Centre vision for sustainability and smart growth. Markham: Town of Markham.

Trudeau, D. (2013). A typology of new urbanism neighborhoods. Journal of Urbanism: International Research on Placemaking and Urban Sustainability, 6(2), 113-138.

Trudeau, D. (2018). Sustaining suburbia through new urbanism: Toward growing, green, and just suburbs? Urban Planning, 3(4), 50-60.

Winstanley, A., Thorns, D. C., \& Perkins, H. C. (2003). Nostalgia, community and new housing developments: A critique of new urbanism incorporating a New Zealand perspective. Urban Policy and Research, 21(2), 175-189.

$\mathrm{Xu}, \mathrm{J}$. L. (2017). Is new urbanism changing the suburban development pattern? A case study of the Toronto region. Journal of Urban Design, 22(6), 812-832.

York Region Rapid Transit Corporation. (2020). Highway 7 East / Markham and Richmond Hill. VivaNext. Retrieved from http://www.vivanext.com/project_ Hwy7East 


\section{COGITATIO}

\section{About the Author}

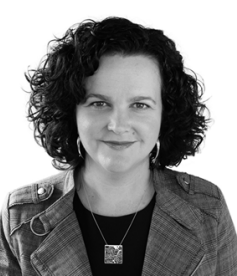

Katherine Perrott is a Professional Planner and a CMHC-SSHRC Postdoctoral Fellow in the Faculty of Environmental and Urban Change at York University, Toronto, Canada. 